served in the same way, makes the record especially valuable.

Mr. Hadden also achieved distinction as an astronomer, and especially in the field of sunspots and other solar phenomena. He had an excellent six-inch telescope, well mounted, in a standard astronomical observatory tower. His standing in this line was recognized by his being a fellow of the Royal Astronomical society.

He made his living as a druggist and served for some years as a member of the state pharmacy board, part of the time as chairman. He gave the public many free lectures on scientific subjects.

The above is a tribute to Mr. Hadden and his professional success as a weather observer at Alta, Iowa, by Director Chas. D. Reed, senior meteorologist, U. S. weather bureau, at Des Moines.

\title{
PETER MELENDY A TOWERING FIGURE
}

Any list of the men who greatly helped in the making of Iowa would be incomplete without the name of Peter Melendy. The present generation does not recognize the name; but he was a towering figure in the last half of the nineteenth century. Between running to fires as a member of a volunteer fire company in Cincinnati and the development of a model farm near that city he had become of the right stature for an Iowa pioneer. Most of his life was at Cedar Falls-farm owner, colonizer, fruit man, organizer of fairs, exhibitor at fairs, promoter of the Iowa college of agriculture, and railroad planner. $\mathrm{He}$ is the man who selected the land grant areas for the college. He helped choose the college's first president. He wrote and spoke and worked for the greater Iowa that was to be because of agriculture.

A very readable and complete story of his life has been prepared by Luella M. Wright and published by the State Historical Society at Iowa City. In the days to come when Iowa history will be better appreciated than now this book will be read with deep interest. Many there are who recall the tall and stately figure of this man in his later days and are glad that his life story has been told. 
Copyright of Annals of Iowa is the property of State of Iowa, by \& through the State Historical Society of Iowa and its content may not be copied or emailed to multiple sites or posted to a listserv without the copyright holder's express written permission. However, users may print, download, or email articles for individual use. 